\title{
Biosorption of $\mathrm{Hg}(\mathrm{II})$ and $\mathrm{Cu}(\mathrm{II})$ by biomass of dried Sargassum fusiforme in aquatic solution
}

\author{
Shengmou Huang and Gan Lin ${ }^{*}$
}

\begin{abstract}
The biosorption of heavy metals $\mathrm{Hg}(\mathrm{II})$ and $\mathrm{Cu}(\mathrm{II})$ from aquatic solution by biomass of dried Sargassum fusiforme was studied in the paper. The Sargassum fusiforme was able to absorb appreciable amount of mercury and copper from the aquatic solutions within 60 min of contact time with the metal solution and exhibited high removal of mercury and copper at low equilibrium concentrations. The specific adsorption of both $\mathrm{Hg}(\mathrm{II})$ and $\mathrm{Cu}(\mathrm{II})$ increased at low concentration of biomass and decreased when biomass concentration exceeded $2.0 \mathrm{~g} / \mathrm{L}$. The binding of mercury followed Freundlich model while copper supported Langmuir isotherm for adsorption with their $r^{2}$ values of 0.971 and 0.923 , respectively. The maximum adsorption per unit masses of Sargassum fusiforme (mg/L) at equilibrium ( $q_{\max }$ ) for $\mathrm{Hg}(I)$ and $\mathrm{Cu}(\mathrm{II})$ were calculated to be 30.86 and $7.69 \mathrm{mg} / \mathrm{g}$, respectively. The biosorption by Sargassum fusiforme was best described using a pseudo-second-order kinetic model for copper and mercury ions in solution in the study. The adsorption was pH dependent as the maximum mercury biosorption and copper adsorption was happened at solution $\mathrm{pH}$ of 8-10.
\end{abstract}

Keywords: Biosorption, Sargassum fusiforme, Mercury, Copper

\section{Background}

The heavy metal is among the most common pollutant found in industrial effluents. The major sources of pollution in the aquatic environment are industries such as paint, pulp and paper, oil refining, electrical, rubber, processing, fertilizer, pharmaceutical and battery manufacturing $[1,2]$. The major effects of mercury and copper poisoning manifest as neurological and renal disturbances as it can easily pass the blood-brain barrier. Environmental contamination with toxic heavy metals is a significant worldwide problem with their successive accumulation in the food chain and continued persistence in the ecosystem which will hurt human beings. Efforts have been made to remove toxic heavy metal from the wastewater and environment by using conserved technologies such as ion exchange or chemical precipitation, which are sometimes inefficient and expensive, particularly for removal of low concentrated heavy metal ions [3], and also leads to produce toxic sludge that adverse the economical feasibility of the treatment methods.

\footnotetext{
* Correspondence: lingan1978@126.com

School of chemical engineering and food science, Hubei University of Arts and Science, Xiangyang 441053, China
}

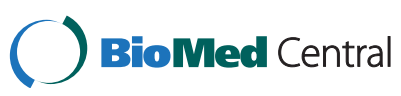

Indeed, many early studies have shown that nonliving biomass may be even more effective than living cells in sequestering metallic elements. Over the past two decades, much effort has been directed at identifying readily available biomass which, in its nonliving state, is capable of effectively removing heavy metals. It has been demonstrated that biosorption is a potential alternative to traditional treatment processes of metal ions removal. Biosorption is a property of certain types of inactive, dead biomass to bind and concentrate heavy metals from even very dilute aqueous solutions [4]. Biomass exhibits this property, acting just as a chemical substance, as an ion exchange of biological origin. Research on biosorption is revealing that it is sometimes a complex phenomenon where the metallic species could be deposited in the solid biosorbent through different sorption processes of ion exchange, complexation, chelation, microprecipitation, etc.

In these years, the role of seagrass in removal of toxic metal ions from the polluted water have taken more importance as they have a high area-to-volume ratio and therefore provide a large contact area for metal binding [5]. Small bacteria, algae, fungi and yeast have been well recognized for heavy metal removal [6]. Up to date, the role of algae has received increased attention to years 
because of it are potential for application of environmental protection as well as recovery of heavy metals. The affinity with various algae species for binding of heavy metals shows different results [7]. Metal ions with greater electro-negativity and smaller ionic radii are preferably absorbed by algae biomass [8]. Metal accumulation capacity of algae biomass is sometimes higher than chemical sorbents therefore algae biomass may serve as an economically feasible to the existing physicochemical methods of metal removal of wastewaters. The major challenge to biosorption studies is to select the most promising biomass from a large pool of available and inexpensive biomaterials. Contributions to Sargassum fusiforme in the metal adsorption is of great concern [9].

In the present study, dried biomass of Sargassum fusiforme were used and characterized for its $\mathrm{Cu}(\mathrm{II})$ and $\mathrm{Hg}(\mathrm{II})$ removal potential from synthetic metal solution. The effect of $\mathrm{pH}$, biomass concentration, initial metal concentration and contact time was studied for metal sorption procedure as well as heavy metal equilibrium sorption kinetics was made in lab.

\section{Methods}

\section{Biosorbent material}

The dry biomass of Sargassum fusiforme were purchased from Fuzhou Lantian limited Company, Fujian (China). It was powdered and sieved into less than $1 \mathrm{~mm}$ in diameter and dried at $80^{\circ} \mathrm{C}$ for $12 \mathrm{~h}$ with drying oven $(01 \mathrm{~A}$, Suzhou sinovel oven manufacturing co., LTD). The characteristics of the Sargassum fusiforme were determined by F-Sorb type 3400 specific surfaces and pore diameter gauge (Beijing gold spectrum technology co., LTD). The surface BET on the algae was of means with $35-40 \mathrm{~m}^{2} / \mathrm{g}$, total pore volume is of $50-70 \%$ and the pore structure is mesoporous material. The FTIR spectrum of the fresh and metal-loaded ones were made by the FTIR920(Tianjin topology instrument co., LTD). The SEM images of the fresh and metal-loaded ones were attained by SU3500 (Hitachi High-Technologies Corporation).

\section{Mercury and copper sorption experiments}

Heavy metal solutions were prepared for diluting $200 \mathrm{mg} / \mathrm{L}$ of stock solutions, which were made by dissolving copper nitrate and mercury nitrate of analytical grade (Shanghai bo yiu biological technology co., LTD) in double distilled water. Metal sorption studies were carried out to evaluate the capacity of dry biomass of Sargassum fusiforme to adsorb metal ions from solutions. In batch ones, $100 \mathrm{~mL}$ of synthetic metal solutions having different concentrations $(10,20,30,40$, and $50 \mathrm{mg} / \mathrm{L})$ of copper or mercury were placed in $250 \mathrm{ml}$ Erlenmeyer flasks with a range of biomass concentrations $(0.5,1.0,1.5 .2 .0,2.5$, and $3.0 \mathrm{~g} / \mathrm{L})$ as biosorbent. Erlenmeyer flasks were kept under shaking at $120 \mathrm{rpm}$ at $25^{\circ} \mathrm{C}$. Samples were taken after 20-120 min and filtered and analyzed for final metal concentration $\left(C_{f}\right)$ using ICP-AES (HK-2000, Huake Beijing tiancheng technology co., LTD) after an acid digestion [10].

To see the effect of $\mathrm{pH}$ on $\mathrm{Hg}(\mathrm{II})$ and $\mathrm{Cu}(\mathrm{II})$ removal, a range of $\mathrm{pH}(2-10)$ was adjusted to $0.1 \mathrm{M} \mathrm{NaOH}$ or $0.1 \mathrm{M}$ $\mathrm{HCl}$ in $100 \mathrm{ml}$ metal solutions containing fixed concentration of metal at $10 \mathrm{mg} / \mathrm{L}$ and biomass of $3.0 \mathrm{~g} / \mathrm{L}$ followed by contact time of $60 \mathrm{~min}$ at rotation of $120 \mathrm{rpm}$. The metal adsorption(q) with Sargassum fusiforme and bioremoval efficiency(R) were calculated by the following formulae.

$$
\begin{aligned}
& q=\left(C_{i}-C_{f}\right) * \frac{V}{M} \\
& R(\%)=\frac{C_{i}-C_{f}}{C_{i}} * 100
\end{aligned}
$$

Where $\mathrm{q}=$ metal adsorption $(\mathrm{mg} / \mathrm{g}) ; \mathrm{M}=$ dry mass of Sargassum fusiforme(g); $\mathrm{V}=$ volume of initial metal solution used (L); $\mathrm{R}=$ bioremoval efficiency (\%); $\mathrm{C}_{\mathrm{i}}=$ initial concentration of metal in aquatic solution $(\mathrm{mg} / \mathrm{L}) ; \mathrm{C}_{\mathrm{f}}=$ final concentration of metal in aquatic solution $(\mathrm{mg} / \mathrm{L})$ [11].

\section{Adsorption isotherm}

During biosorption, the equilibrium is established between absorbed metal ion on the Sargassum fusiforme(q) and unabsorbed metal ions in the solution $\left(\mathrm{C}_{\mathrm{f}}\right)$. This equilibrium represented by Langmuir and Freundlich adsorption isotherms, are widely used to analyze data for wastewater treatment application [12]. Langmuir equation, which is valid for monolayer sorption onto a surface, with identical sites was given by Eq. 3 .

$$
q=q_{\max } * b * \frac{C_{f}}{1+b C_{f}}
$$

Where $\mathrm{q}_{\max }(\mathrm{mg} / \mathrm{g})$ is the maximum amount of the metal ion per unit weights of algae to form a complete monolayer on the surface bound at high $C_{\mathrm{f}}(\mathrm{mg} / \mathrm{L})$, and $\mathrm{b}$ is a constant related to the affinity of the binding sites $(\mathrm{mg} / \mathrm{L})$, $\mathrm{q}_{\max }$ represents a practical limiting adsorption capacity when the surface is fully covered with metal ions and assists in the comparison of adsorption performance [13]. The $\mathrm{q}_{\max }$ and $\mathrm{b}$ can be determined from the liner plot of $\mathrm{C}_{\mathrm{f}} / \mathrm{q}$ versus $\mathrm{C}_{\mathrm{f}}$. The empirical Freundlich equation based on sorption on a heterogeneous surface is given below by Eq. 4.

$$
q=k * C_{f}^{1 / n}
$$

The $\mathrm{k}$ and $\mathrm{n}$ parameters are the constants of the Freundlich isotherm. The $\mathrm{k}$ and $\mathrm{n}$ are indicators of 
adsorption capacity and adsorption intensity, respectively. The Eq.4 can be linearized in logarithmic forms and Freundlich constants can be determined by the plot. Freundlich isotherm is also more widely used as it provides no information on the monolayer adsorption capacity [14].

\section{Biosorption kinetics}

The experimental biosorption kinetic data was modeled using the pseudo-first-order (Eq.5), and pseudo-secondorder models (Eq.6). The linear pseudo-first-order model can be represented by the following equation:

$$
\log \left(q_{e}-q_{t}\right) \log q_{e}-\frac{K_{1}}{2.303} * t
$$

The qe $(\mathrm{mg} / \mathrm{g})$ and $\mathrm{qt}(\mathrm{mg} / \mathrm{g})$ are the amounts of adsorbed metal on the sorbent at the equilibrium time and at any time $t$, respectively, and $K_{1}\left(\mathrm{~min}^{-1}\right)$ is the rate constant of the pseudo-first-order adsorption process. The linear pseudo-second-order model can be represented by the following equation:

$$
t / q_{t}=\frac{1}{K_{2}} * q_{e}^{2}+\frac{t}{q_{e}}
$$

Where $\mathrm{K}_{2}\left(\mathrm{~g}^{*} \mathrm{mg}^{-1 *} \mathrm{~min}^{-1}\right)$ is the equilibrium rate constant of pseudo-second-order [11].

\section{Results and discussion}

\section{Effect of $\mathrm{pH}$ solution}

The $\mathrm{pH}$ is one of the important parameters in heavy metal sorption by Sargassum fusiforme. Therefore metal sorption studies were carried out at different $\mathrm{pH}$ values. Results revealed the maximum biosorption of $\mathrm{Hg}$ (II) were at $\mathrm{pH} 8(70 \%)$ and $10(72 \%)$ and $\mathrm{Cu}(\mathrm{II})$ demonstrated the same result at $\mathrm{pH} 8(90 \%)$ and $10(92 \%)$ from aquatic solution containing initial $10 \mathrm{mg} / \mathrm{L}$ of metal concentration (Figure 1).

It was observed that $\mathrm{Hg}$ (II) and $\mathrm{Cu}$ (II) adsorption was less than $10 \%$ at $\mathrm{pH} 2$. Enhance adsorption of $\mathrm{Hg}$ (II) and $\mathrm{Cu}$ (II) ions at higher $\mathrm{pH}$ was observed which coincides with earlier findings where in most cases the removal efficiency increased steadily with rise in $\mathrm{pH}$ [15]. The adsorption of metal ions was lower at low $\mathrm{pH}$ because of high concentration of protons in the solution which competed with metal ions in forming a bond between the active sites on the surface of the algae biomass [16]. Selective sorption of specific metals due to distinct $\mathrm{pH}$ optima for their sorption may be due to the chemical composition of cell surfaces. A distinct relationship between $\mathrm{pH}$ of aquatic metal solutions and involvement of functional group in binding of $\mathrm{Hg}$ (II) and $\mathrm{Cu}$ (II) onto Sargassum fusiforme maxima was observed with the involvement of functional groups such as carboxyl, phosphate and hydroxyl [17].

\section{Metal concentration}

Biosorption studies carried out for both $\mathrm{Hg}(\mathrm{II})$ and $\mathrm{Cu}$ (II) in $100 \mathrm{ml}$ solutions containing metals varying from 10 to $50 \mathrm{mg} / \mathrm{L}$ with $\mathrm{Hg}(\mathrm{II})$ and $\mathrm{Cu}(\mathrm{II})$ by $3.0 \mathrm{~g} / \mathrm{L}$ of biomass exhibited effective role of initial metal concentration on metal removal. A consistent decrease in metal removal was observed by increasing external metal concentration (Figure 2) where 70-74\% removal efficiency was reported on 10 to $20 \mathrm{mg} / \mathrm{L} \mathrm{Hg}$ (II) solutions followed by decline in solutions to $50 \mathrm{mg} / \mathrm{L} \mathrm{Hg}(\mathrm{II})$ (Figure 2). Similarly decreases in $\mathrm{Cu}$ (II) removal efficiency was observed by increasing external metal concentration on $50 \mathrm{mg} / \mathrm{L} \mathrm{Cu}$ (II) (Figure 2). Rapid metal adsorption profile of Sargassum fusiforme was obtained for both $\mathrm{Hg}(\mathrm{II})$ and $\mathrm{Cu}(\mathrm{II})$, which is important when the algae are used for biosorption. It

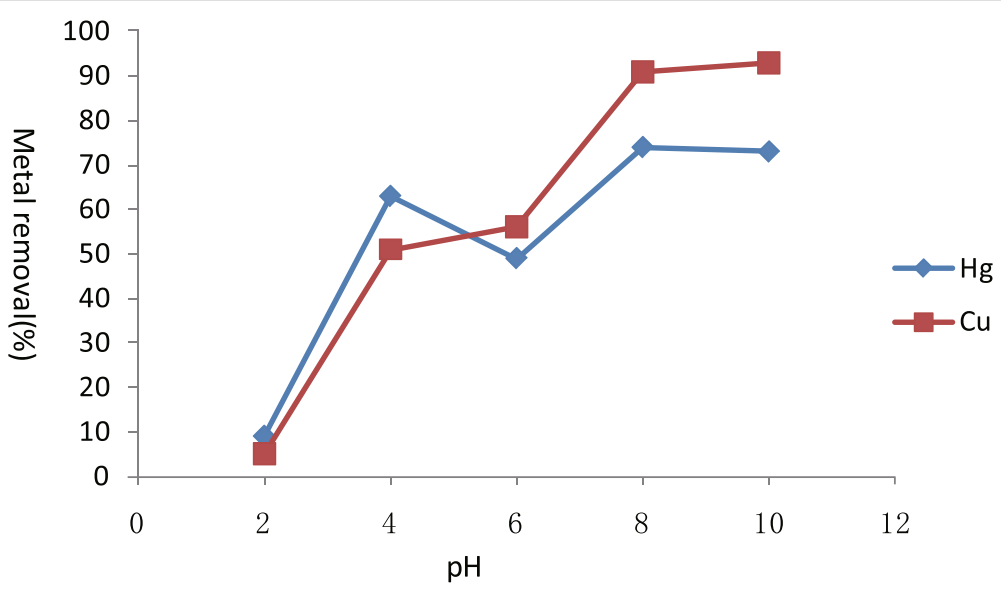

Figure $1 \mathrm{pH}$ dependent sorption of $\mathrm{Hg}(\mathrm{II})$ and $\mathrm{Cu}(\mathrm{II})$ by Sargassum fusiforme( $\mathrm{Hg}(\mathrm{II}): 10 \mathrm{mg} / \mathrm{L}, \mathrm{Cu}(\mathrm{II}): 10 \mathrm{mg} / \mathrm{L})$, standard deviation is less than $5 \%$ in triplicates. 


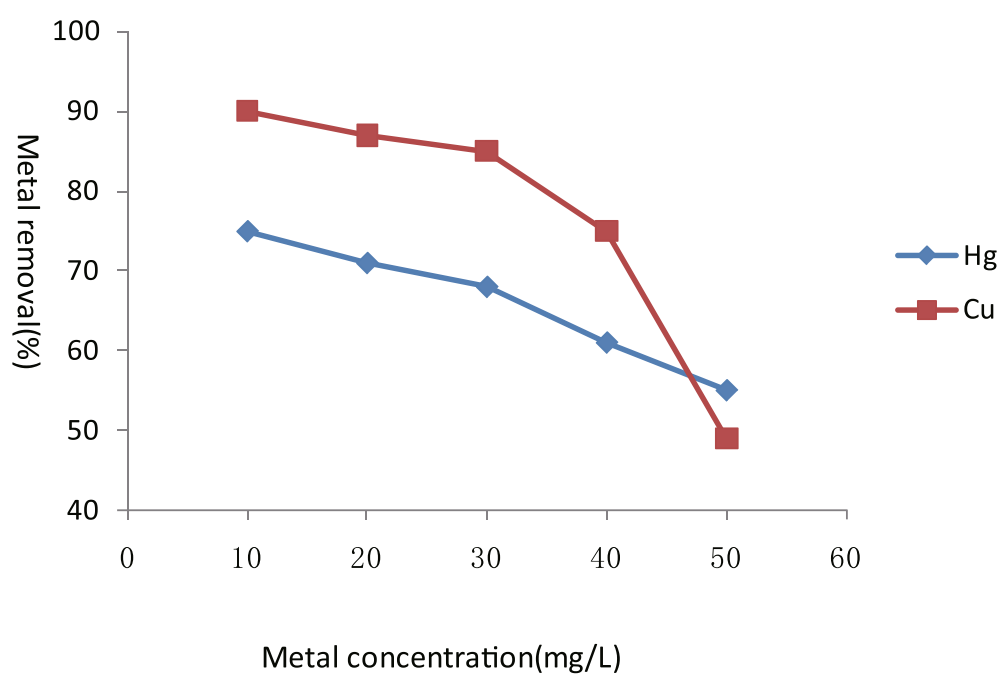

Figure 2 Initial concentration dependent sorption of $\mathrm{Hg}(\mathrm{II})$ and $\mathrm{Cu}(\mathrm{II})$ by Sargassum fusiforme, standard deviation is less than $5 \%$ in triplicates.

exhibited rapid biosorption at first $60 \mathrm{~min}$ by removing $72 \% \mathrm{Hg}$ (II) and $90 \%$ of $\mathrm{Cu}$ (II) from metal solutions. Decreases in metal removal of increasing initial metal concentration was supported by the findings that observed that the removal of metal generally decreases from increasing concentration of metals in the solution [18]. Algae surface has different functional groups of varying the affinity with ionic kinds, therefore decline in metal removal is largely attributed to saturation of adsorption sites [7].

\section{Contact time determination}

Rapid metal adsorption profile of Sargassum fusiforme was obtained for both $\mathrm{Hg}(\mathrm{II})$ and $\mathrm{Cu}(\mathrm{II})$, which is important when the material is to be used for biosorption. It exhibited rapid biosorption in first $60 \mathrm{~min}$ by removing $71 \% \mathrm{Hg}(\mathrm{II})$ and $88 \%$ of $\mathrm{Cu}(\mathrm{II})$ from metal solutions thereafter increase in metal removal was magical. Equilibrium was established between absorbed metal ions after 40 min with maximum removal of 55\% and $75 \%$ of $\mathrm{Hg}(\mathrm{II})$ and $\mathrm{Cu}(\mathrm{II})$ (Figure 3).

The Sargassum fusiforme biomass showed rapid biosorption at first $60 \mathrm{~min}$. It has been reported that the sorption of heavy metal ions by algae followed mechanism where the metal ion is physically or chemically taken up onto the surface of the algae [19]. In this case, since the algae were dried and biological functions were no longer active, the sorption could only take place on the

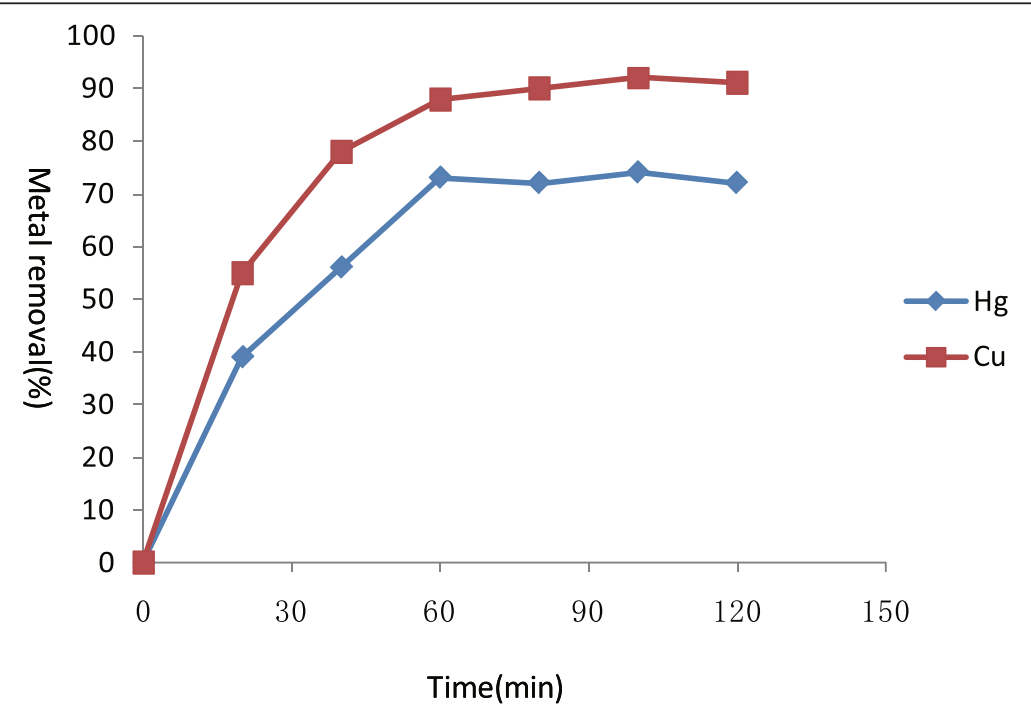

Figure 3 Time dependent removal of $\mathrm{Hg}(\mathrm{II})$ and $\mathrm{Cu}(\mathrm{II})$ by Sargassum fusiforme( $\mathrm{Hg}(\mathrm{II}): 10 \mathrm{mg} / \mathrm{L}, \mathrm{Cu}(\mathrm{II}): 10 \mathrm{mg} / \mathrm{L})$, standard deviation is less than $5 \%$ in triplicates. 


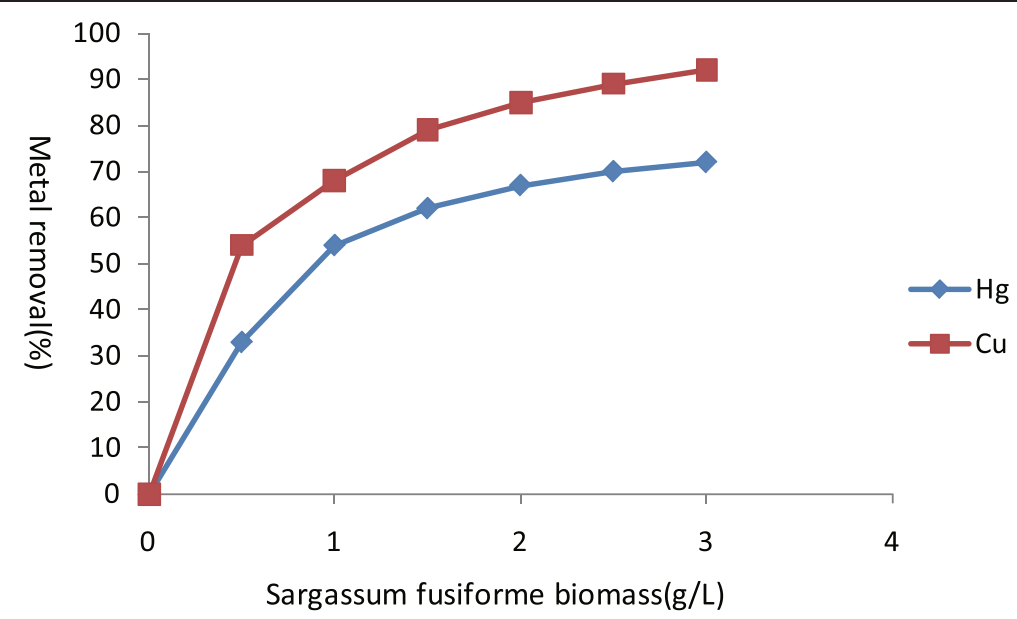

Figure 4 Effect of Sargassum fusiforme biomass concentration on $\mathrm{Hg}(\mathrm{II})$ and $\mathrm{Cu}(\mathrm{II})$ removal(Hg(II):10 mg/L, $\mathrm{Cu}(\mathrm{II}): 10 \mathrm{mg} / \mathrm{L}), \mathrm{standard}$ deviation is less than $5 \%$ in triplicates.

cell surface. The increase in $\mathrm{Hg}(\mathrm{II})$ and $\mathrm{Cu}(\mathrm{II})$ adsorbed by increasing biomass was also expected as a result of increase in available area-to-volume ratio and therefore providing a large contact area for heavy metal binding [20].

\section{Biomass determination}

Increase in metal removal efficiency from $10 \mathrm{mg} / \mathrm{L}$ manual metal solutions to both $\mathrm{Hg}(\mathrm{II})$ and $\mathrm{Cu}(\mathrm{II})$ was observed on increasing biomass concentration (Figure 4).

$\mathrm{Hg}$ (II) adsorption was increased to $71 \%$ by increasing biomass concentration on 0 to $3.0 \mathrm{~g} / \mathrm{L}$ in $10 \mathrm{mg} / \mathrm{L}$ of mercury containing synthetic solutions whereas, same trend was observed in case of $\mathrm{Cu}(\mathrm{II})$ with the increase of 90\%. The Sargassum fusiforme biomass displayed its equilibrium for $\mathrm{Hg}(\mathrm{II})$ removal of $3.0 \mathrm{~g} / \mathrm{L}$ of biomass concentration whereas, a continuous increase in $\mathrm{Cu}$ (II) removal of increasing biomass concentration was observed of $3.0 \mathrm{~g} / \mathrm{L}$. Metal adsorption studies from solution mass balance revealed a decline in sorption of $\mathrm{Hg}(\mathrm{II})$ and $\mathrm{Cu}$ (II) respectively by increasing biomass from 0 to $3.0 \mathrm{~g} / \mathrm{L}$ after $60 \mathrm{~min}$ of contact time. The other probable explanations for such a relationship between biomass concentration and adsorption may be limited availability of metal, increased electrostatic interactions between binding sites and reduced mixing at higher biomass concentration [21,22].

\section{The FTIR and SEM analysis}

With the determination of functional matrices and group in the heavy metal biosorption of the algae, it is useful for the study of FTIR spectrums. The figures are shown in Figure 5. With the determination of biosorption kinetics and isotherms in the heavy metal biosorption of the algae, the use of SEM images is shown in Figure 6 for the study.

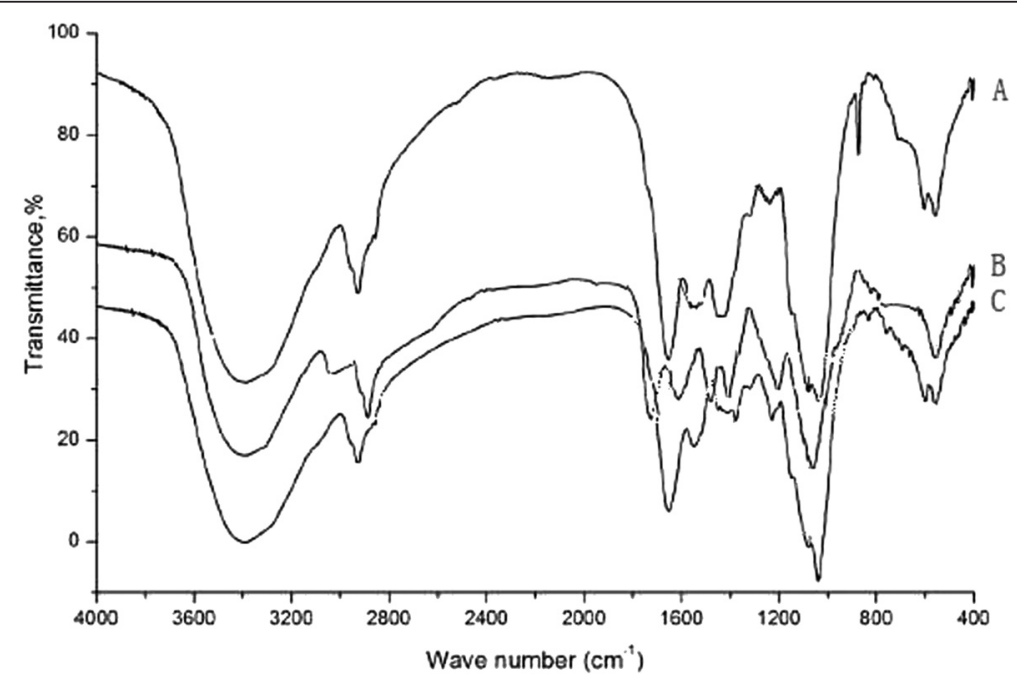

Figure 5 The FTIR spectrum of the adsorbent for fresh and metal loaded ones. A: fresh, B: Cu(II) loaded, C: Hg(II) loaded. 

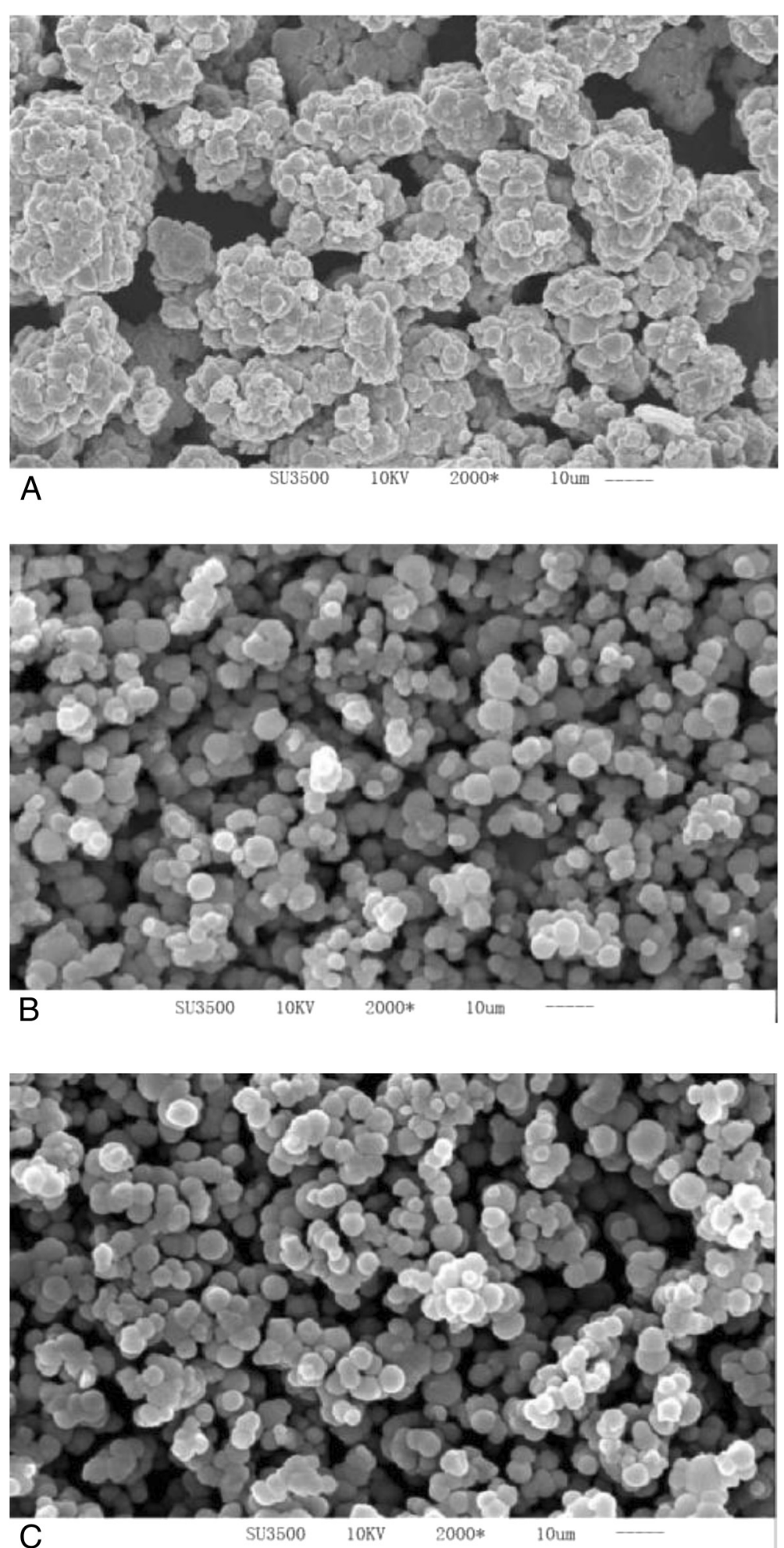

Figure 6 The SEM images of the adsorbent for fresh and metal loaded ones. A: fresh, B: Cu(II) loaded, C: Hg(II) loaded.

\section{Modeling study}

A linear regression of the experimental results from $\mathrm{Hg}(\mathrm{II})$ and $\mathrm{Cu}(\mathrm{II})$ differed in terms of $\mathrm{Hg}(\mathrm{II})$ adsorption fitted better to Freundlich isotherm and $\mathrm{Cu}(\mathrm{II})$ to Langmuir isotherms with $r^{2}$ values of 0.971 and 0.823 respectively (Table 1). The maximum adsorption per unit masses of 
Table 1 Langmuir and Freundlich parameters for the sorption of the test metals by Sargassum fusiforme

\begin{tabular}{|c|c|c|c|c|c|c|}
\hline \multirow[t]{2}{*}{ Metal } & \multicolumn{3}{|c|}{ Langmuir isotherm } & \multicolumn{3}{|c|}{ Freundlich isotherm } \\
\hline & $\overline{b(L / m g)}$ & $r^{2}$ & qmax(g/mg) & $\bar{K}(\mathrm{mg} / \mathrm{g})$ & $\mathrm{n}$ & $r^{2}$ \\
\hline $\mathrm{Hg}(\mathrm{II})$ & 0.988 & 0.668 & 30.86 & 2.012 & 3.89 & 0.971 \\
\hline $\mathrm{Cu}(\|)$ & 1.269 & 0.923 & 7.69 & 0.899 & 5.41 & 0.765 \\
\hline
\end{tabular}

Sargassum fusiforme $(\mathrm{mg} / \mathrm{L})$, at equilibrium $\left(\mathrm{q}_{\max }\right)$ for $\mathrm{Hg}$ (II) and $\mathrm{Cu}$ (II) were calculated to be 30.86 and $7.69 \mathrm{mg} / \mathrm{g}$ respectively (Table 1).

The sorption isotherm is the relationship between equilibrium concentration on the solution and equilibrium concentration of solute in the sorbent at constant temperature where either Freundlich or Langmuir model can describe the biosorption equilibrium of copper and mercury [23]. An extremely high $r^{2}$ value of Freundlich isotherm for $\mathrm{Hg}$ (II) sorption indicated that ion exchange interaction takes place between metal ion and the biosorbent, while $\mathrm{Cu}(\mathrm{II})$ follows Langmuir isotherm and thus supported physicochemical interactions with each other.

For biomasses of Sargassum fusiforme, the kinetics of copper and mercury biosorption were analyzed using pseudo-first-order and pseudo-second-order models. All the constants and regression coefficients are shown in Table 2. In the present study, biosorption by Sargassum fusiforme was best described using a pseudo-secondorder kinetic models for copper and mercury ions in solution. This adsorption kinetic is typical of the adsorption of divalent metals onto biosorbents.

\section{Conclusions}

The goal of the study was to explore and find out the potential use of algae biomass as a low cost sorbent for the removal of heavy metals from aquatic solutions. The heavy metals $\mathrm{Hg}(\mathrm{II})$ and $\mathrm{Cu}(\mathrm{II})$ from aquatic solution was able to be dealt with dried Sargassum fusiforme. The seagrass adsorbed appreciable amount of mercury and copper from the aquatic solutions within $60 \mathrm{~min}$ at low equilibrium concentrations. The specific adsorption of both $\mathrm{Hg}$ (II) and $\mathrm{Cu}$ (II) increased at low concentration while decreased when biomass concentration exceeded $2.0 \mathrm{~g} / \mathrm{L}$. The binding of mercury followed Freundlich model but copper supported Langmuir isotherm for adsorption with their $\mathrm{r}^{2}$

Table 2 First and second order adsorption rate constants for $\mathrm{Hg}$ (II) and $\mathrm{Cu}$ (II)

\begin{tabular}{llllll}
\hline Metal & \multicolumn{2}{l}{ Pseudo-first-order } & & \multicolumn{2}{l}{ Pseudo-second-order } \\
\cline { 2 - 3 } & $\mathbf{K}_{\mathbf{1}}\left(\mathbf{m i n}^{-\mathbf{1}}\right)$ & $\mathbf{r}^{\mathbf{2}}$ & & $\mathbf{K}_{\mathbf{2}}\left(\mathbf{g}^{*} \mathbf{m g}^{-\mathbf{1}} \mathbf{m i n}^{\mathbf{- 1}}\right)$ & $\mathbf{r}^{\mathbf{2}}$ \\
\hline $\mathrm{Hg}(\mathrm{II})$ & $5.3^{*} 10^{-3}$ & 0.745 & & $9.15^{*} 10^{-3}$ & 0.957 \\
$\mathrm{Cu}(\mathrm{II})$ & $3.1^{*} 10^{-3}$ & 0.615 & & $8.84^{*} 10^{-3}$ & 0.963 \\
\hline
\end{tabular}

values of 0.971 and 0.923 , respectively. The maximum adsorption per unit masses of Sargassum fusiforme (mg/L), at equilibrium $\left(\mathrm{q}_{\max }\right)$ for $\mathrm{Hg}(\mathrm{II})$ and $\mathrm{Cu}$ (II) were calculated to be 30.86 and $7.69 \mathrm{mg} / \mathrm{g}$ respectively. The adsorption was $\mathrm{pH}$ dependent as the maximum mercury biosorption utilized at $\mathrm{pH} 8$ and 10 and $\mathrm{Cu}(\mathrm{II})$ adsorption was at $\mathrm{pH} 8$ and 10. The biosorption by Sargassum fusiforme was best described using a pseudo-second-order kinetic model for copper and mercury ions in solution in the study. The present paper emphasizes the Sargassum fusiforme is an ideal candidate and can be designed as a practical and economical process for wastewater treatment polluted by heavy metals.

\section{Competing interests}

The authors declare that they have no competing interests.

\section{Authors' contributions}

HSM and LG conceived the work, performed the experiments, designed the experiments, analyzed the data, and wrote the manuscript. Both authors read and approved the final manuscript.

\section{Acknowledgments}

We greatly thank Chen Guantong from FAU for providing researching materials in this investigation. We are also grateful to Zhang Danfeng for the helpful comments and linguistic revision of the manuscript. This work was supported by grants from the ministry of education from Hubei province, People's Republic of China(project No. Q20122506).

Received: 29 September 2014 Accepted: 9 March 2015

Published online: 17 March 2015

\section{References}

1. Rezaee A, Ramavandi B, Ganati F. Biosorption of mercury by biomass of filamentous algae Spirogyra species. J Biol Sci. 2006;6(4):695-700.

2. Khodaverdiloo $H$, Samadi A. Batch equilibrium study on sorption, desorption, and immobilisation of cadmium in some semi-arid zone soils as affected by soil properties. Soil Res. 2011;49:444-54.

3. Lu WB, Shi JJ, Wang CH, Chang JS. Biosorption of lead, copper and cadmium by indigenous isolate Enterobacter sp. Processing high heavy metal resistance. J Hazard Mater. 2006;134:80-6.

4. Rezaee A, Ramavandi B, Ganati F. Equilibrium and spectroscopic studies on biosorption of mercury by algae biomass. Pak J Biol Sci. 2006;9(4):777-82.

5. Pandiyan S, Mahendradas D. Application of bacteria to remove Ni(II) lons from aqueous solution. Eur J Sci Res. 2011;52:345-58.

6. Ekmekyapar F, Aslan A, Bayhan YK, Cakici A. Biosorption of copper (II) by nonliving lichen biomass of Cladonia rangiformis hoffm. J Hazard Mater. 2006;B137:293-8.

7. Zouboulis Al, Loukidou MX, Matis KA. Biosorption of toxic metals from aqueous solution by bacterial strains isolated from metal-polluted soils. Process Biochem. 2004;39:909-16.

8. Anjana K, Kaushik A, Kiran B, Nisha R. Biosorption of $\mathrm{Cr}(\mathrm{VI})$ by immobilized biomass of two indigenous strains of cyanobacteria isolated from metal contaminated soil. J Hazard Mater. 2007;148:383-6.

9. Naik UC, Srivastava S, Thakur IS. Isolation and characterization of Bacillus cereus IST105 from electroplating effluent for detoxification of hexavalent chromium. Environ Sci Pollut Res Int. 2011;19:3005-14.

10. Vijayaraghavan K, Jegan J, Palanivenu K, Velan M. Biosorption of cobalt(II) and nickel(II) by seaweeds: batch and column studies. Sep Purif Technol. 2005;44:53-9.

11. Ok YS, Yang JE, Zhang YS, Kim SJ, Chung DY. Heavy metal adsorption by a formulated zeolite-Portland cement mixture. J Hazard Mater. 2007;147:91-6.

12. Kaewsarn P, Yu Q. Cadmium (II) removal from aqueous solutions by pretreated biomass of marine alga Padina sp. Environ Pollut. 2001;112:209-13.

13. Chatterjee SK, Bhattacharjee I, Chandra G. Biosorption of heavy metals from industrial waste water by Geobacillus thermode nitrificans. J Hazard Mater. 2010;175:117-25 
14. Lodeiro P, Barriada $J \mathrm{~L}$, Herrero R, Sastre deVicente ME. The marine macroalga Cystoseira baccata as biosorbent for cadmium (II) and lead (II) removal: kinetic and equilibrium studies. Environ Pollut. 2006;142:264-73.

15. Vilar VJP, Botelho CMS, Boaventura RAR. Lead uptake by algae Gelidium and composite material particles in a packed bed column. Chem Eng J. 2008;144:420-30.

16. Costodes VCT, Fauduet $\mathrm{H}$, Porte $\mathrm{C}$, Delacroix A. Removal of $\mathrm{Cd}(\mathrm{II})$ and $\mathrm{Pb}(\mathrm{II})$ ions from aqueous solutions by adsorption onto sawdust of Pinus sylvestris. J Hazard Mater. 2003;105:121-42.

17. Pabst MW, Miller CD, Dimkpa CO, Anderson AJ, McLean JE. Defining the surface adsorption and internalization of copper and cadmium in a soil bacterium Pseudomonas putida. Chemosphere. 2010;81:904-10.

18. Sari $\mathrm{A}$, Tuzen $\mathrm{M}$. Biosorption of $\mathrm{Pb}(\mathrm{II})$ and $\mathrm{Cd}(\mathrm{II})$ from aqueous solution using green alga (UIva lactuca) biomass. J Hazard Mater. 2008;152:302-8.

19. Oliveira SM, Pessenda LC, Gouveia SE, Favaro DI. Heavy metal concentrations in soils from a remote oceanic island, Fernando de Noronha. Braz An Acad Bras Cienc. 2011;83:1193-206.

20. Pardo R, Herguedas M, Barrado E, Vega M. Biosorption of cadmium, copper, lead and zinc by inactive biomass of Pseudomonas putida. Anal Bioanal Chem. 2003;376:26-32.

21. Wang $X S$, Qin $Y$. Removal of $\mathrm{Ni}(\mathrm{II}), \mathrm{Zn}(\mathrm{II})$ and $\mathrm{Cr}(\mathrm{VI})$ from aqueous solution by Alternanthera philoxeroides biomass. J Hazard Mater. 2006;138:582-8.

22. Xiong J, He Z, Liu D, Mahmood Q, Yang X. The role of bacteria in the heavy metals removal and growth of Sedum alfredii Hance in an aqueous medium. Chemosphere. 2008;70:489-94.

23. Mata YN, Blazquez ML, Ballester A, Gonzalez F, Munoz JA. Characterization of the biosorption of cadmium, lead and copper with the brown alga Fucus vesiculosus. J Hazard Mater. 2008;158:316-23.

\section{Submit your next manuscript to BioMed Central and take full advantage of:}

- Convenient online submission

- Thorough peer review

- No space constraints or color figure charges

- Immediate publication on acceptance

- Inclusion in PubMed, CAS, Scopus and Google Scholar

- Research which is freely available for redistribution 